OBSERVATION OF LUMINESCENT SPECTRA

IN LOW-ENERGY ION-NEUTRAL COLLISIONS

Progress Report

For Period June 1, 1980 - May 31, 1981

\title{
J. J. Leventhal
}

University of Missouri - St. Louis

St. Louis, Missouri 63121

\section{NOTICE}

This report was prepared as an account of work sponsored by the United States Government. Neither the United States nor the United States Department of Energy, nor any of their employees, nor any of their contractors, subcontractors, or their employees, makes any warranty, express or implied, or assumes any legal liability or responsibility for the accuracy, completeness, or usefulness of any information, apparatus, product or process disclosed or represents that its use would not infringe privately owned rights.

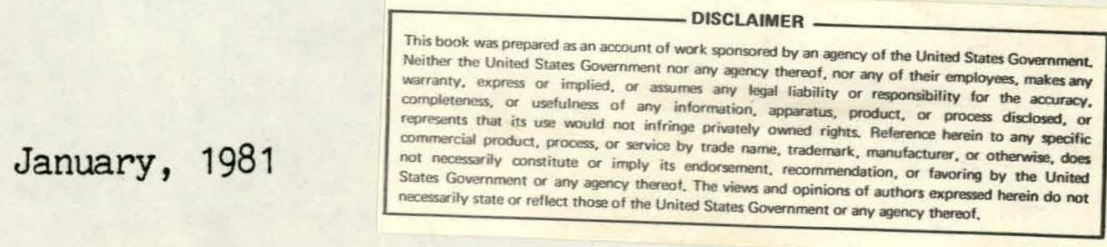

Prepared For

THE U. S. DEPARTMENT OF ENERGY

UNDER CONTRACT NO. DE-AS02-76-ERO2718 


\section{DISCLAIMER}

This report was prepared as an account of work sponsored by an agency of the United States Government. Neither the United States Government nor any agency Thereof, nor any of their employees, makes any warranty, express or implied, or assumes any legal liability or responsibility for the accuracy, completeness, or usefulness of any information, apparatus, product, or process disclosed, or represents that its use would not infringe privately owned rights. Reference herein to any specific commercial product, process, or service by trade name, trademark, manufacturer, or otherwise does not necessarily constitute or imply its endorsement, recommendation, or favoring by the United States Government or any agency thereof. The views and opinions of authors expressed herein do not necessarily state or reflect those of the United States Government or any agency thereof. 


\section{DISCLAIMER}

Portions of this document may be illegible in electronic image products. Images are produced from the best available original document. 
TABLE OF CONTENT

ABSTRACT ......................... 3

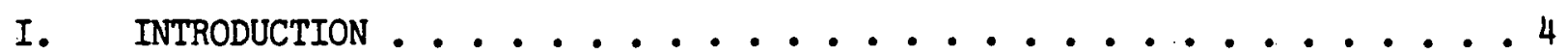

II. LASER-ASSISTED CHARGE TRANSFER ................ 5

III. ENERGY POOLING ..................... 8

IV. TRAPPED LIFETIME EXPERIMENTS . . . . . . . . . . . . . 11

V. REFERENCES . . . . . . . . . . . . 14

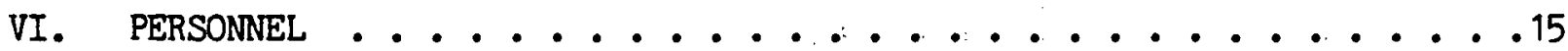

VII. Appendix I. Laser-Enhanced Lyman- $\alpha$ Production in Collisions Between Hydrogen Ions and Sodium Atoms, V. S. Kushawaha, C. E. Burkhardt and J. J. Leventhal, Phys. Rev. Lett. 45, 1686 (1980) . . . . . . . . 16

VIII. Append1x II. Energy Pooling in $\mathrm{Na}(3 \mathrm{p})-\mathrm{Na}(3 \mathrm{p})$ Collisions, V. S. Kushawaha and J. J. Leventhal, Phys. Rev. A22, $2468(1980)$. . . . . 19

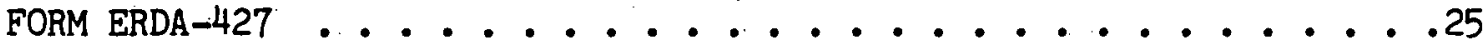




\section{ABSTRACT}

This report describes work performed during the past year. Experiments on energy pooling in excited atom/excited atom collisions and laser enhanced charge transfer were performed and reported in the scientific literature. Work continued on these aspects of the program as well as on experimental studies of trapping of resonance radiation. 


\section{INTRODUCTION}

This report describes work done in the past year in the Atomic and Molecular Physics Laboratory at UMSL. The primary objective is to perform experiments designed to obtain data on energy transfer and energy partitioning in inelastic atomic and molecular collisions. A variety of techniques are employed including emission spectroscopy and atomic beam methods.

During the past year progress was made in three aspects of this program:

1. Laser-assisted charge transfer

2. Energy pooling in excited atom/excited atom collisions

3. Trapped lifetime experiments

These topics will be discussed separately. 


\section{Laser Assisted Charge Transfer}

These experiments are designed to investigate reaction selectivity based on reactant internal energy. This kind of selectivity is of interest because such processes have been proposed as possible methods for isotope separation. In addition reactions involving excited species have been studied as a potential means of producing population inversions. Our intention has been to study the fundamental nature of such processes by examining simple collision systems. We chose the proton sodium system to begin our work. Although a number of unanticipated experimental problems that hampered progress on these experiments were encountered, studies of $\mathrm{H}^{+}-\mathrm{Na}$ were completed during the past year and the results reported in The Physical Review Letters ${ }^{1}$.

Briefly, we wish to compare the yield of Lyman $\alpha$ (L $\alpha$ ) radiation from the reaction

$$
\mathrm{H}^{+}+\mathrm{Na}(3 \mathrm{~s})+\mathrm{H}(\mathrm{n}=2)+\mathrm{Na}^{+}
$$

with that from the reaction

$$
\mathrm{H}^{+}+\mathrm{Na}(3 \mathrm{p})+\mathrm{H}(\mathrm{n}=2)+\mathrm{Na}^{+}
$$

Reaction (1) is endothermic by $1.74 \mathrm{eV}$ while reaction (2) is exothermic by $0.34 \mathrm{eV}$. Since the potential energy curves for $\mathrm{H}(\mathrm{n}=2)-\mathrm{Na}+11$ e closer to the $\mathrm{H}^{+}-\mathrm{Na}(3 \mathrm{p})$ curve than the $\mathrm{H}^{+}-\mathrm{Na}(3 \mathrm{~s})$ curve it is expected that reaction (2) will have $\exists$ larger cross section than reaction (1). 
The apparatus for these experiments is shown schematically in Figure 1. A mass selected proton beam of variable kinetic energy $(1-2000 \mathrm{eV})$ is directed into a cell containing sodium vapor at $\sim 10^{13}$ atoms $/ \mathrm{cm}^{3}$. For these experiments the cell is illuminated with light from a cw tunable dye laser which can be mechanically chopped. On one side of the cell there is a slot leading to an optical system (monochromator and photomultiplier) for detecting and dispersing collision-produced radiation in the wavelength range 2000-8500. This optical system can be used, as it has been in the past, to obtain collision-produced emission spectra for the purpose of diagnosing inelastic ion-atom or ion-molecule collision processes. It can also be used in experiments involving laser excitation when appropriate; in this case a "notch" absorption filter is used to eliminate most of the intense laser-induced resonance fluorescence radiation which would otherwise damage the photomultiplier tube.

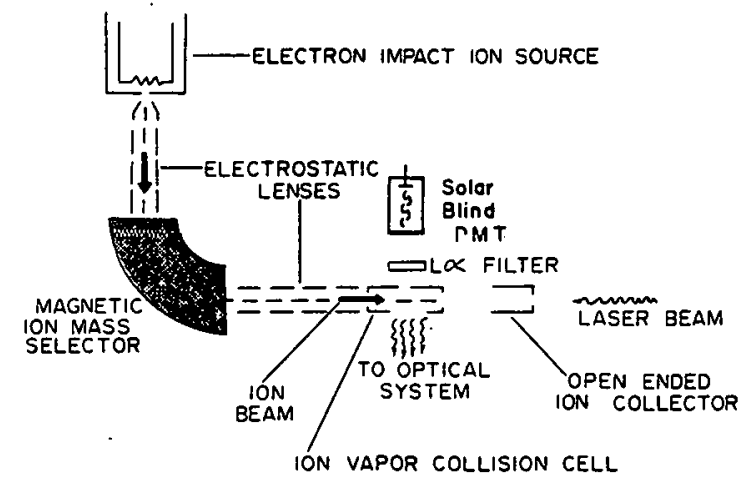

Figure 1. Schematic diagram of the apparatus used in laser assisted charge transfer experiments.

There is a $3 \mathrm{~mm}$. diameter hole on the side of the cell opposite the optical system. This hole may be used to extract ions from the interaction region for mass analysis or, as in the present case, to pass vuv radiation. 
The vuv radiation is detected with a solar blind photomultiplier as shown. To select $L \alpha$, a $1216 \AA$ narrowband filter is interposed between the cell and the photomultiplier. A dual counter, synchronized with the mechanical light chopper, is used to compare the "laser on" to "laser off" conditions, and thus assess the relative roles of reactions 1 and 2 .

Our results show that the expected enhancement occurs, but only for kinetic energies below about $30 \mathrm{eV}$. We also demonstrated that neither $\mathrm{H}_{2}{ }^{+}-\mathrm{Na}$ nor $\mathrm{H}_{3}{ }^{+}-\mathrm{Na}$ collisions produced a measureable enhancement of $\mathrm{L} \alpha$ or any radiation at or near the $\mathrm{L} \alpha$ wavelength (such as radiation from excited $\mathrm{H}_{2}$ molecules). Further details are given in Appendix I which is a reprint of the paper in The Physical Review Letters. 
These experiments are designed to investigate the fundamental nature of energy transfer processes involving two atoms or molecules, each of which is in an excited state. Our studies so far have concentrated on reactions of the type

$$
\mathrm{Na}(3 p)+\mathrm{Na}(3 p)+\mathrm{Na}(\mathrm{nl})+\mathrm{Na}(3 \mathrm{~s})
$$

and

$$
\mathrm{Na}(3 p)+\mathrm{Na}(3 p)+\mathrm{Na}_{2}{ }^{+}+\mathrm{e}
$$

For both Reactions (3) and (4) the indicated products are formed by "pooling" the internal energy of two 3p sodium atoms. In fact, in Reaction (3) if the $\mathrm{n}$ l sodium state lies higher than twice the 3p energy $(2.1 \mathrm{eV})$ then kinetic energy is also required to drive the reaction. Thus "energy pooling" reaction in this context could refer to a process that requires a combination of internal energy from both reactants and possibly conversion of reactant kinetic energy into internal energy to access the products.

After our initial report of our observation of such processes ${ }^{2}$ we began a systematic study of $\mathrm{Na}(3 \mathrm{p})-\mathrm{Na}(3 \mathrm{p})$ collisions. The apparatus used in these experiments is shown schematically in Figure 2.

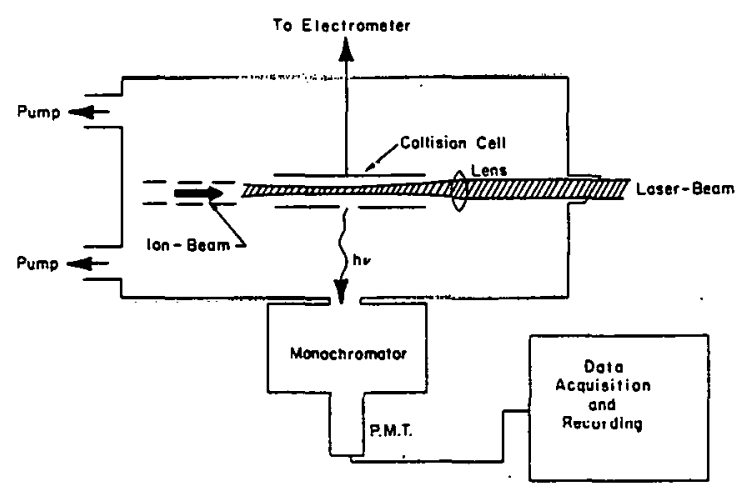

Figure 2. Schematic diagram of the apparatus used in energy pooling experiments. 
A Spectra-Physics Model 580 single frequency dye. laser pumped by a 5 watt $\mathrm{Ar}^{+}$laser, and tuned to either of the sodium $\mathrm{D}_{1}$ or $\mathrm{D}_{2}$ lines is used to excite sodium atoms to the $3 p$ state. A small fraction of the laser beam is directed into a $2 \mathrm{GHz}$ FSR, $13 \mathrm{MHz}$ bandwidth confocal interferometer, Spectra-Physics Model 470-3, and displayed on an oscilloscope to monitor frequency stability. The main laser beam is focused into the collision cell and the laser power density varied using a set of calibrated neutral density filters.

In addition to the apertures for the laser beam, the collision cell has a $2 \mathrm{~cm}$ long X $2 \mathrm{~mm}$ wide slot parallel to the laser beam. Photons emanating from the collision cell that pass through the slot may be dispersed with a $0.25 \mathrm{~m}$. scanning monochromator. A notch filter with transmission $10^{-7}$ at $589 \mathrm{~nm}$ is used to attenuate the $589 \mathrm{~nm}$ fluorescence from the sodium vapor. However the transmitted signal is usually high enough to detect and provides a convenient monitor at the $\mathrm{Na}(3 \mathrm{p})$ population. After passing through the monochromator, photons are detected with a cooled photomultiplier tube used in the counting mode. Ions formed in the laser-excited vapor are collected on an electrode inserted into the collision cell, and the ion current measured with an electrometer. A small transverse electric field ensures complete ion collection. Althnugh both $\mathrm{Na}^{+}$and $\mathrm{Na}_{2}^{+}$ions are known to be formed in the laser-excited vapor, the origin of the $\mathrm{Na}^{+}$has been determined to be photodissociation of $\mathrm{Na}_{2}{ }^{+}$so that the total ion signal is a measure of incipient $\mathrm{Na}_{2}+$.

Sodium vapor is introduced into the collision cell from an oven located beneath the cell. This configuration is necessary to minimize blackbody radiation in the optical system. For this reason the reading on a thermocouple mounted in the oven cannot be used to infer the sodium atom 
density in the cell. Instead, the atom density, $n$, is presently determined by directing a mass selected $\mathrm{N}_{2}+$ ion beam into the cell, and observing the $589 \mathrm{~nm}$ radiation resulting from collision induced excitation in $\mathrm{N}_{2}{ }^{+}-\mathrm{Na}$ collisions. This signal, together with the previously measured absolute cross section for this $\mathrm{N}_{2}{ }^{+}-\mathrm{Na}^{3}$ process, leads to a determination of $\mathrm{n}$ as a function of the oven thermocouple reading.

Experiments performed within the past year were directed toward verifying the processes responsible for the observed products, and determining rate constants for these processes. Temperature dependences were also investigated. The results of this work was reported in The Physical Review ${ }^{4}$; a reprint of the paper is included in this report as Appendix II. 


\section{Trapped Lifetime Experiments}

This work was begun with the anticipation that it would lead to an alternative to those methods currently employed for determining atom densities in metal vapor. Because our collision cell is cooler than the oven from which the $\mathrm{Na}$ atoms emanate, and because the cell has openings for ion extraction, the temperature of the oven cannot be correlated with the atom density, $n$. As noted in the previous section of this report we use ion impact on sodium atoms in conjunction with a previously measured cross section for the inelastic process

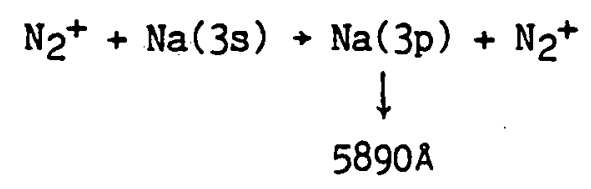

to determine $n$ in our energy pooling experiments. The "previously measured" cross section was determined using a surface ionization detector. For experiments involving other alkali atoms processes analogous to Reaction (5) are employed.

Our new method is based on the well-known effect of imprisonment of resonance radiation. It has long been known that the measured lifetime, $\tau^{*}$, of an atomic (or molecular) state can be longer than the natural lifetime, $\tau$, of the state if the time decay of a resonance line is used for the lifetime measurement. Since the final state of a resonance line (in emission) is the atomic ground state, nearby atoms in the ground state may reabsorb emitted resonance radiation. Thus, observation of resonance radiation emitted by excited atoms may be delayed due to this trapping effect. The apparent lifetime then is expected to be a function of the atom density and the 